\title{
ACCESSIBILITY OF LOCAL FOOD PRODUCTION TO REGIONAL MARKETS - CASE OF BERRY PRODUCTION IN NORTHERN OSTROBOTHNIA, FINLAND
}

Kirsi Korhonen, Ossi Kotavaara, Toivo Muilu, Jarmo Rusanen ${ }^{1}$

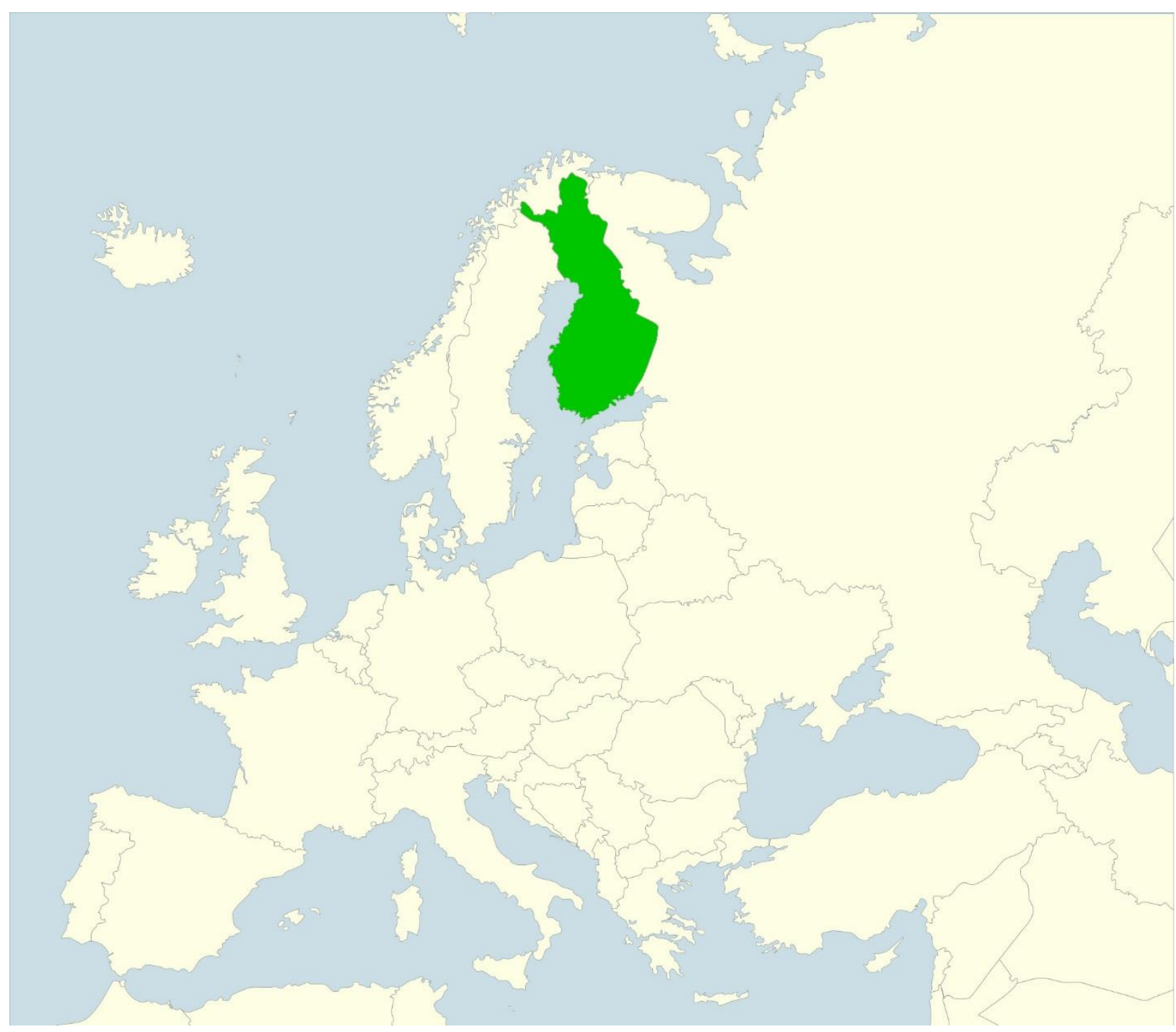

\footnotetext{
${ }^{1}$ M.Sc. Kirsi Korhonen, Research Scientist, Natural Resources Institute Finland, Paavo Havaksen tie 3, FI-90014 University of Oulu, kirsi.korhonen@luke.fi; Ph.D. Ossi Kotavaara, Geography Research Unit, P.O.Box 3000, FI-90014 University of Oulu, ossi.kotavaara@oulu.fi; Research Professor Toivo Muilu, Natural Resources Institute Finland, Paavo Havaksen tie 3, Fl-90014 University of Oulu, toivo.muilu@luke.fi; Professor Jarmo Rusanen, Geography Research Unit, P.O.Box 3000, FI-90014 University of Oulu, jarmo.rusanen@oulu.fi
} 
Abstract: Consumers and institutional kitchens, as well as traders, have shown increasing interest towards local food. This is particularly due to the transparency and traceability characteristic of a short supply chain and social aspects related to food origins. The trend has been increasingly common during the past decade in Europe and North America, and it is strongly evident in the case area of this study in Northern Ostrobothnia, Finland. In general, ease of access to food is highly important for consumers and crucial for institutional kitchens, in addition to quality aspects and price. However, regardless of proximity, poor accessibility is one of the key issues preventing the further growth of local food markets. Due to scale economics in food value chain, food transport is presently organised mainly by centralised, large-scale logistics companies directed via hubs serving millions of consumers. Accordingly, production volumes required to enter large-scale markets are often unattainable for disjointed small-scale local food producers. In this study, geographic information system (GIS)-based accessibility analyses are applied for analysing potential for integral networking of local food production and transport companies. Berry production was selected as a case study because it has a relatively strong role in Northern Ostrobothnia, while its logistics are notably underdeveloped. Spatial data of primary production volumes consists of register records of farm-specific cultivation areas and average yields in Northern Ostrobothnia and Finland. Accessibility computations are based on the digital model of the Finnish road network, Digiroad. Two surveys were also implemented to farmers and food processing companies to seek views on food processing, sales, logistics and procurements regarding local food. Data from the surveys was used in accessibility analysis, which enables exploration of opportunities for establishing 'local food' clusters integrating small producers into a more effective and competitive network. Information about favourable conditions for cooperative networks in the local food sector may help in establishing companies and their growth. Again, successful networking may increase scale economies in local production in transport, processing and marketing.

Keywords: accessibility, berry production, geographic information systems (GIS), local food, location allocation, Northern Ostrobothnia, Finland

\section{Introduction}

There is evidently increasing interest towards local food and alternative food networks, originating from the dissatisfaction with conventional food systems (e.g. Harris 2010). Consumers are more commonly interested in the origin, freshness and unprocessed nature of food (Brown 2003; Saito \& Saito 2013; Feldmann \& Hamm 2015). Food produced close to its consumption environment is quite commonly perceived to be both environmentally and economically sustainable (e.g. Norberg-Hodge et al. 2002; Morgan 2008). Advocates of local food pay attention especially to the reduced environmental impacts of transportation (Edward-Jones et al. 2008: 265) but the sustainability of local food chains compared to global ones is not always unambiguous (Brunori et al. 2016). However, the nutritional quality, of fruits and vegetables especially, may be affected by the various activities that occur along the supply chain (Edward-Jones et al. 2008: 271). Local food is also perceived to have much in common with organic food (Isoniemi et al. 2006: 3) with the idea of purity and production without artificial fertilizers and plant protection products.

Local food and short supply chains are seen as valuable within European Union policies and national implementations and significant efforts are directed toward their research and development (see Kneafsey et al. 2013; Puoskari et al. 2013; Korhonen \& Muilu 2016). The current EU rural development policy 2014-2020 has increased emphasis on short food supply chains and local food (EPRS 2016). In addition, local food has gained share in public procurements, while many EU member states have identified that local food promotes sustainability (European Commission 2012). Purchases from nearby producers is considered to 
be an applicable instrument in agriculture and rural policies (e.g. Marsden et al. 2000) as well as an efficient way to support environmentally friendly products and services (Green public procurement 2008).

In Finland, local food has been on the political agenda, especially since 2010 and it is clearly recognised as a future growth sector in the Government Programmes (Finland's $72^{\text {nd }}$ government 2013; Valtioneuvoston kanslia 2015). A Government report on food policy (Valtioneuvosto 2010) and the proposal for a national food strategy (Huomisen ruoka 2010) promoted local and organic as a separate development areas. The National Local Food Programme (Finland's $72^{\text {nd }}$ government 2013) is a steering instrument in support of the Government local food policy during the EU programming period 2014-2020 and it is implemented through the administrative means and development work covering all actors in the local food chain. A new Government report on food policy Food2030 (Valtioneuvosto 2017) was published in spring 2017. The report sets out the policy objectives and key priorities of the activities until 2030.

In 2011, the share of local food in the consumer goods was estimated at $8 \%$ and that in the supply of special food stores, restaurants, cafes and public institutions were estimated at $10 \%$ (Kurunmäki et al. 2012). Each year the public sector in Finland spends about 350 million euros on purchasing food and its raw material (Finland's $72^{\text {nd }}$ government 2013). A higher share of local food would increase the amount of revenue remaining in the region, increase job opportunities, as well as allow taking local food culture into account in meals offered in institutional kitchens. According to Viitaharju et al. (2014), local food seems to have some economic potential for Finnish regions. With the case of the province of South Savo in Finland, Seppänen et al. (2006) studied the potential effects of local food in the regional economy, and they found that locally produced food has positive impacts on the regional economy, while at the same time it seems that focusing foodstuff sales within a local region increases the output of the regional economy, adds value and the demand for labour. Particularly, regions dependent on agriculture and the food industry have opportunities to renew and promote business activities through local food.

It has been recognised that growth in the food sector can be founded on the natural resource strengths of Finland, including abundant and pure soil and water resources, which provide pure raw materials for food. In addition, it has been identified that climate change and the consequent global shortage of water may also enhance Finland's role as a food producer. Besides many other objectives, the National Local Food Programme (Finland's $72^{\text {nd }}$ government 2013) also stated that there is an aim for advanced logistics for small batches, allowing profitable and sustainable business. The programme describes logistics challenges as follows (p.10):

The logistics challenges are a good example of operations where cooperation between actors in the food chain is particularly important... It is important to create company-driven regionally networked wholesale arrangements and functioning profitable distribution chains that are also suited for very small batches... achieving large enough product volumes, secure deliveries and diverse ranges of products calls for new kinds of networked business operations and creating the conditions for the growth of, for example, entrepreneurship based on cooperatives. The opportunities offered by the current structures must also be taken into account in developing the logistics solutions.

Logistics cooperation is deeply organised around the typical primary production in Finland such as livestock and milk production, and logistics chains are highly functional towards wholesale and retail. However, in the case of local food, the logistics is presently distributed via extremely small operators and mainly by the farmers. Berry production is also a strong field of agriculture in Northern Ostrobothnia but its logistics are notably underdeveloped. Additionally, the degree of processing around berry production is relatively low and its food safety regulations are lighter compared to livestock, for instance, so it is a highly suitable case for this study (see Kotavaara et al. 2014). This paper focuses on tackling the challenges related to logistics of small-scale local food production, which in Finland are partly a consequence of the sparse spatial structure of agricultural production and population.

This study develops an accessibility method for analysing potential for integral networking of producers and transport companies by combining qualitative analysis and quantitative geographic information system (GIS)-based analysis. There is a vast body of locational analyses for 
optimising facility sites routes in the context of transports (see Miller \& Shaw 2001), but transport questions related to local food are rarely analysed. Bosona and Gebresenbet (2011) investigated local food supply networks in sight of large-scale food distribution centres and identified computationally suitable gravity centre locations for local food clusters in Sweden. Moreover, to integrate local food producers within networks of suppliers, distributors, customers and community representatives in order to increase their competitiveness, Bosona et al. (2013) have evaluated the performance of an integrated food distribution network in Sweden, by GIS-based location and route analyses including data of producers, customers and distributions centres. Again, producer-specific data has been applied recently for developing gastro tourism in the case of beer routes optimised to visit small-scale breweries and beer houses in Hungary (Csapó \& Wetzl 2016).

In this paper, we seek to assess opportunities to establish a centralised logistics services for small scale berry producers using Northern Ostrobothnia as a case study. Information about favourable conditions for cooperative networks in the local food sector may help in establishing companies and stimulate their growth, and successful networking may increase scale economies in local production in transport, processing and marketing. A potential service provider could be a small or medium-sized logistics operator but the study setting was designed to consider a form of logistics service not yet provided in this context. The piloted methodical frame will be applicable also to other fields of production than the mainly seasonal case study of berries. Concrete objectives of this study are formulated as research questions:

1. What are the circumstances, needs and challenges in small-scale local food transport?

2. What are the most suitable sites for locating local food collection logistics operator, when allocated by vehicle routing based analysis?

\section{Local food markets, logistics and value chain}

Renting et al. (2003) have specified different types of alternative food networks. In their study they specifically discuss short food supply chains (SFSC) such as organic farming, quality production and direct selling. In SFSCs producer-consumer relations are "shortened" and defined by origin and quality-related attributes. According to Halweil (2002: 40), the international success of direct marketing channels of food to consumers suggests that there is strong support for local food systems. Halweil states that the success is due to the high quality of products and the social interactions they provide, which puts direct marketing in a niche that anonymous grocery shops and multinational food corporations cannot fill. The first category of SFSCs presented by Renting et al. (2003: 399-400) is particularly based on face-to-face interaction such as farm shops, farmers' markets and roadside sales. The second category of SFSCs however is based on relations of proximity; this includes actions such as farm shop groups and community-supported agriculture, for example. Even so, Renting et al. emphasise that SFSCs are the results of active construction of networks by different actors in the food chain, rather than the results of the external and elusive "free market".

Regulation (EU) No 807/2014 provides that the definition of local markets eligible for support by the European Agricultural Fund for Rural Development (EAFRD) shall be defined in Member States' rural development programmes. However it states that kilometric distance from the farm, taking into account specific geographic features of the area concerned should be used as a criterion defining local food markets, unless a convincing alternative criterion is presented. The concept of local food in Finland is usually used to refer to the foodstuff of which the origin is geographically traceable (Mononen 2006) and there are two commonly used definitions for local food. In 2000 the Finnish Working Group on Local Food (Maaseutupolitiikan yhteistyöryhmä 2000) defined locally produced food to be production and consumption of food that uses raw materials and inputs of its own region of production, and promotes the economy and employment of the region. The Central Union of Agricultural Producers and Forest Owners (MTK 2011) defines local food as fresh, Finnish food produced as nearby as possible, with a known origin, producer and manufacturer. According to Kotavaara et al. (2014), the definition of local food varies a little among different actors in the supply chain. As a comparison, to be considered local or as a short food chain in France, the distance around the farm should not exceed 80 kilometres (Blanquart 
et al. 2010). There is no agreed distance limit for local food in Finland and in general discussion the distance limit varies usually from 50 to 100 kilometres. On the other hand, the discussions about local food in Finland commonly refer to products which are produced in the same province where they are used.

The sustainable growth of the local food sector may be organised by cooperative structures which allow smaller producers to access larger markets as part of a bigger whole. This is one very promising trend that will increase local food profitably (see Seyfang 2006; Berti \& Mulligan 2016). According to Lagnevik et al. (2003) in food industry clusters, mobility of the labour force and demanding consumers are the most important factors in stimulating knowledge creation and exchange about processes, technologies and consumer tastes, thus keeping knowledge flows open and building a successful cluster. Beckie et al. (2012) have studied the role of clustering within farmers' markets in western Canada. There are few other food industry studies that have utilised a clustering framework for analysing agglomeration within local food networks (see Donald 2009; Lawson et al. 2008). Porter (1998: 199) defines clusters as a geographically proximate group of interconnected companies and institutions in a particular field, linked by commonalities and complementarities. According to Beckie et al. (2012), there is however a distinction between spatial agglomeration or co-location and active clustering while firms may be located near one another but have little interaction, sharing of ideas or resources. Porter (1998: 15) stated that social interaction and trust form the social infrastructure needed for knowledge exchange to take place and they are an essential part of the glue that holds clusters together. According to Wolfe and Gertler (2006), spatial proximity and face-to-face encounters are important for building trust and knowledge exchange, especially in the early stages of cluster formation.

The concept of value chain was first presented by Porter (1985) describing the process of a specific commodity from a raw material into a finished product. Rapidly expanding consumer demand for local food has increased the supply of local food in various distribution channels and the evaluation of its value chain. Bloom and Hinrichs (2011) have studied how the features of the value chain structure operate when conventional food system infrastructures incorporates local food into their overall operations. They state that policy-makers and practitioners seeking to support the 'scaling up' of local and regional food systems should consider targeted development of technical infrastructure in processing and distribution, as well as outreach on appropriate shared ownership models. In Finland, Virtanen et al. (2014: 40-41) have studied the value chain of local food as a value network starting from raw materials and ending to the consumer. Direct sales and food buying clubs are seen as the shortest value chains where the demand and supply are clearly met. However, in these kinds of value chains, the problem is the scale of activity. Often entrepreneurs' values and attitudes do not support business growth and, consequently, the volume of business is quite small for individual companies. In the shortest value chains, the expansion of operations can lead to a rise in logistics costs and hence to the operation rationalization needs.

It has been identified that in the case of small producers in Finland, lack of competitive logistics and small volumes limit the access of products to markets via centralised flows and it is really important that local food producers develop networks with each other (see Piilo 2003; Järvelä et al. 2009). Also, on the international level the lack of mid-scale aggregation and distribution systems in particular has been noted (see Day-Farnsworth et al. 2009). To increase competitiveness and market access of local food, new logistical solutions are needed and transport accessibility plays a key role in this. In Finland, especially among institutional kitchens the lack of logistics is one important reason why local food procurements are seen as quite inconvenient (Puoskari et. al. 2013; Vänttinen \& Korpi-Vartiainen 2010). In a Finnish case study Piilo et al. (2007) surveyed the needs of small and medium-sized enterprises (SMEs) and developed different transportation solutions. The objective of the project was to create transport and distribution solutions for local food producers and farmers outside the Helsinki area so that they could more effectively reach their customers: restaurants and stores in Helsinki. Two networks were created in the meat and bakery sector and logistical operation models were piloted in 28 enterprises. After the end of the project, one entrepreneur had realised $48 \%$ savings in his 
transportation costs. However, there is clearly a lack of academic research considering local food accessibility in the context of cooperative networks of small producers.

\section{Methods and data}

The study develops and applies transport accessibility methods (Miller \& Shaw 2001) to explore opportunities for establishing 'local food' clusters integrating small producers into an effective and competitive network by the simplified routing location models approach (see Nagy \& Salhi 2007). The study assesses numerical suitability of potential locations for logistic centres in sight of accessible producers. Accessibility analyses and data management are implemented by GIS. Spatial data of primary production volumes consists of register records of farm-specific cultivation areas and average yields in Northern Ostrobothnia and Finland. Accessibility computations are carried out by using the digital model of Finnish road network, Digiroad, which includes speed limits for travel time and route estimation.

The design and parameters for accessibility analyses are built upon the results of two questionnaires and six interviews implemented in 2013. Questionnaires were given to agricultural producers ( $\mathrm{N}=957 ; 179$ responses with $18.7 \%$ response rate) and food processing companies $(\mathrm{N}=278 ; 51$ responses with $18.3 \%$ response rate) to seek views on local food and its availability as well as food processing, sales, logistics and procurements. Agricultural producers receiving the survey were selected so that all producers practicing in direct selling to consumers, organic farming or growing rarer species were included. The survey was also sent to the 20 biggest farms determined by the number of farm animals. In addition, all farms with other food businesses, such as processing were included. Berry production was practised to some extent by 217 farms. The survey for food processing companies was addressed to all known actors in Northern Ostrobothnia and additionally to a few other companies located outside, but near the region's borders. To survey the local food transport systems in detail, interviews focused on all clearly local food-oriented companies in the study region.

Relevant models for food transport accessibility measuring in the context of small-scale food production are self-managed producer-to-centre transports corresponding to $p$-median location allocation (Campbell 1996) and transport service-based collection routes applied by Bosona \& Gebresenbet (2011). This study develops an approach considering locational advantages of a centralised logistics operator by establishing the latter type of analysis. To inspect opportunities to locate a collection site optimally in relation to a potential collection network, spatial data consisting of primary production at the farm level was gathered from the Information Centre of the Ministry of Agriculture and Forestry. Farm-specific information includes area under cultivation, which is transformed to a production estimate by average hectare yield data of each berry plant based on average hectare production at the country or county level. Data was connected to the accurate model of the road network including speed limits for travel time estimation and routing functions. Analysis in this study is executed by applying vehicle routing function to proxy an optimal collection route reaching production of farms optimally from potential collection centre locations.

\section{Demands and needs for development of a local food transport system in Northern Ostrobothnia}

Generally, large companies dominate the food sector and in the European Union there is significant concentration within both the industry producing foodstuffs and the retail industry in the food sector (European Commission 2001). In Finland, the food industry today is the fourth largest industrial sector with a gross value added to production of 13.2 billion euros (ETL 2016), resulting to $7.1 \%$ of GDP, whereas the share of agriculture is only $2.8 \%$. The Finnish food industry is characteristically bipolar, having few large food business companies whose products cover the majority of products and services in the sector and reach all Finnish consumers and their awareness. Also, the food markets in Finland are dominated by local indigenous firms and in particular, the Finnish grocery market particularly is very concentrated and even duopolistic (OECD 2014, see also Muilu et al. 2016). 
In addition to large companies, there are numerous small companies competing in the market, usually with a more limited variety of products (OECD 2014). According to the statistics compiled by Ruoka-Suomi (2013), there were in total 2931 food companies in Finland in 2013 and 83\% of those were microenterprises employing less than 10 people. In the same year, the number of food companies in Northern Ostrobothnia was 231 and almost $90 \%$ of those employed were fewer than ten people. Most of the food processing companies $(78.4 \%, \mathrm{~N}=40)$ responding to our survey were also quite small and employed under ten people. However, the turnover was over 900,000€ among $36 \%$ of all companies. The most common industries were bakeries, fish processing and meat industry.

The study region, province of Northern Ostrobothnia (Fig. 1), has a population of 411,000 (in 2017) and a land area of $44089 \mathrm{~km}^{2}$. Almost half of the population live in the provincial centre in the city of Oulu, and the rest of the population is mostly located in the southern half of the region where the primary production is mainly located. In 2013, there were 4,689 agricultural and horticultural enterprises in the Northern Ostrobothnia region while the most common production sectors were milk production $(27.8 \%)$, cereals production $(25.4 \%)$ and other plant production $(26.0 \%)$. The utilised agricultural area of agricultural and horticultural enterprises in Northern Ostrobothnia was 226827 hectares in total and 48.37 hectares per farm on average. This number is much larger than in other European Union Member States that averaged 16.1 hectares in 2013 (EUROSTAT 2016). Apart from cereal and potato production the majority of food plant farms in Northern Ostrobothnia produce berries, especially strawberry and blackcurrants. In addition, the share of processing vegetables, berries and fruits in the region is $18.6 \%$ while the amount in Finland is $15.7 \%$. Thus, berry production has a relatively strong role in Northern Ostrobothnia.

The farm size of agricultural producers responding to the survey of this study varied from one hectare to almost 400 hectares, when the average size was about 57 hectares. The most common main production line was cereal production (Table 1). The main production line of the majority of farms which had berry production to some extent $(\mathrm{N}=56)$ was either cereal production, other horticultural production or outdoor horticultural production. $40 \%$ of all farms responding to the survey were in organic production, however, the actual share of organic farms in the region was $14 \%$ in 2016.

Tab 1. Main production lines of agricultural producers (included if at least on 5 farms, $N=168$ ).

\begin{tabular}{|l|l|l|l|l|l|l|}
\hline $\begin{array}{l}\text { cereal } \\
\text { production }\end{array}$ & $\begin{array}{l}\text { other } \\
\text { horticultural } \\
\text { production }\end{array}$ & $\begin{array}{l}\text { dairy } \\
\text { farming }\end{array}$ & $\begin{array}{l}\text { outdoor } \\
\text { horticultural } \\
\text { production }\end{array}$ & $\begin{array}{l}\text { beef } \\
\text { farming }\end{array}$ & $\begin{array}{l}\text { specialty } \\
\text { crop } \\
\text { production }\end{array}$ & $\begin{array}{l}\text { sheep } \\
\text { farming }\end{array}$ \\
\hline $29.6 \%$ & $17.3 \%$ & $16.8 \%$ & $10.6 \%$ & $8.4 \%$ & $7.3 \%$ & $3.9 \%$ \\
\hline
\end{tabular}

When access of products to grocery markets is limited due to low volumes, small producers and active consumers organised direct sales, farmers markets and food circles and other alternative food chains, which also help producers to increase their profits. The trade relies, however, on specialised consumers and lower accessibility in rural areas limits growth opportunities. Our surveys revealed the need of a local food wholesaler or other logistical feature integrating local products. Food processing companies have realised the market value of local products and are interested in using them more. In Finland, food companies operating at a small scale are usually local food producers by nature and their importance to local food markets is undeniable. Studies (e.g. Forsman 2004) show that most of the raw material acquisition and sale of the products takes place within the region where they are located. According to our survey addressed to agricultural producers, one of the most important distribution channels for them seemed to be local food processing companies (about one third of producers mentioned this channel). Also, about twothirds of local food processing companies purchased raw-materials directly from producers within their own area and almost $60 \%$ expressed their willingness to use more local foodstuff. In addition, the market areas of food processing companies involved in the study were mostly local, while over a third identified their main market area to be their own or a neighbouring municipality and over a quarter stated it to be their own or neighbouring province. 
According to agricultural producers and food processing companies requirements on price level, requirements related to the amounts of supply, lack of knowledge about potential customers and their needs and problems related to logistics have a negative effect on delivering products to local actors. Food processing companies considered that enhanced supply, co-operation of farmers, processors and consumers, a local food wholesale or other logistics integrating products, local food outlets and joint transportation for products all require development.

\section{Accessibility to berry production by type}

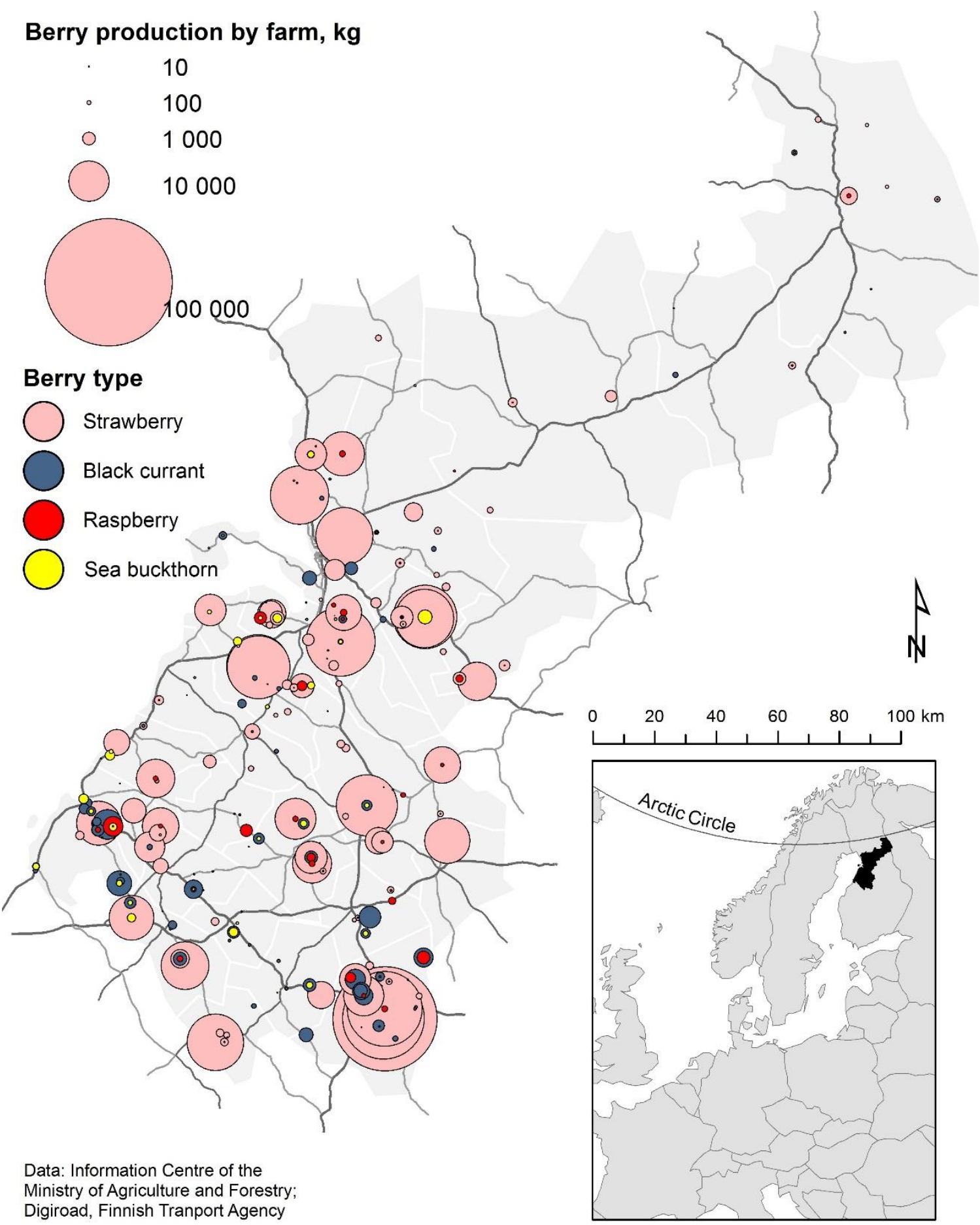

Fig 1. Production estimates for farms by types in Northern Ostrobothnia. 
Logistical cooperation and precisely, cooperation in transportation is important especially among smaller actors (see Piilo et al. 2007). However, surveys revealed that only about $10 \%$ of agricultural producers cooperated in transportation. About a third of all agricultural producers transport products on their own. Transportation was most frequent during the growing season and it occurred daily or even several times a day. Almost a third transported products once or twice a week and about a half less frequently. Transportation was the most commonly done via vans. The average transport distance was 50.7 kilometres $(\mathrm{N}=51)$ with a maximum transport distance of 100.5 kilometres $(\mathrm{N}=44)$. The transport duration time was estimated to be about a minimum of three hours (2.98 hours) and this is used in the accessibility analyses later on in this study. The value is formed by extracting the most active producers transporting products by evaluating variables related to direct sales, amount of production, production sector, frequency of transport and means of transport, the latter standing for van or equivalent, most typically $(\mathrm{N}=20)$. The average transport duration time for all producers responding to the question was almost the same (3.2 hours, $\mathrm{N}=51$ ).

About a half of all producers had storage functions available. Producers bought services for storing, packing and deliveries from external operators, but mainly not more frequently than once a month. Food processing companies had mainly their own storage space, but also services from external operators were bought. Some of the food processing companies had their own transportation and some used services from external operators, and the majority (67\%) used both.

According to the surveys, the most common distance limit for local food was 100 kilometres. As mentioned before, there is no agreed upon distance delimiting what is considered local food in Finland, but in general discussion the distance limit varies usually from 50 to 100 kilometres. When defining it from the viewpoint of administrative boundaries, about $45 \%$ of all respondents considered that the most fitting place of origin for local food was the respondent's own municipality or a neighbouring one and the same amount considered it to be primarily Northern Ostrobothnia or the neighbouring province. The most important feature of local food is that there are as few elements in the supply chain as possible.

\section{Evaluating potential sites for berry production collection sites}

The simplified routing location allocation analysis of this study is designed to assess suitability of potential local food collection sites in sight of accessibility. Analysis is carried out by routing a collection vehicle and by measuring accessible production from each potential site within conventional transport time-mileage. There are vast numbers of techniques to determine optimal facility locations which apply transport accessibility measures (Klose \& Drexl, 2005). Typically, accessibility measures consist of two basic components: the travel cost and the quality or quantity of opportunities (Páez et al. 2012). In this study, the fastest route travel time estimates are used as proxies for transport efforts and reached opportunities consist of farm-specific food production in kilograms. Location allocation (i.e. geographic optimisation) for a facility is commonly executed by, e.g., p-median with the idea that customers travel to access services of a facility (Miller \& Shaw 2001).

A differing approach of this study focuses on analysing how well collection transports could reach products at farms when routes are optimised. In other words, location of collection sites are optimised with the idea that a logistics service provider operates a delivery van which picks up products from farms. Again, the farmer does not drive and transport, like p-median allocation supposes.

Accessibility computations of this study are, in practice, based on a cumulated opportunities index, referring to opportunities reached within a certain threshold value in distance friction (see Spiekermann, et al. 2015), but instead of back-and-forth routes, collection 'milk run' routes area was applied (Figure 2). In this type of analysis, location and routing analyses are strongly interrelated. Thus, modelling type is defined as 'routing location models' including both the classical location problem and the vehicle routing problem (Nagy and Salhi, 2007). The complicated optimisation task is simplified in this study, by limiting analysis to one depot, a five-route "fleet" and 3-, 6- or 9-hour routes, case specifically (the last one on the basis of maximum allowable driving time according to EU and Finnish legislation). Analyses are carried 
out by using geographic information system (GIS)-based accessibility computations carried out by using ESRI ArcGIS and Python 3.0 scripts.

Simulated collection networks are generated by optimising a set of five routes to reach a maximum amount $(\mathrm{t})$ of berry production at farms with a defined time-cost $(\mathrm{h})$. Calculation is executed with the idea that any of the farm locations could potentially be a collection site. Thus, collection networks consist of a set of optimal delivery routes, having a start and end point at the depot site and the optimal route to reach freight nodes efficiently.

In route solving, the study applies the ArcGIS vehicle route problem (VRP) tool designed for routing several vehicles accessing several destinations with differing weights. The VRP route solver seeks the solution for the determination of a set of routes, each performed by a single vehicle which starts and ends at its own depot, fulfilling all customer requirements and minimising transport costs (see Baldacci et al., 2010). VRP is a superset of the classical traveling salesman problem, which is a combinatorial problem and thus further developed 'tabu search metaheuristics' are in the background of the analysis. However, ESRI (2010) does not share the functions of route solving openly.

Key factors for implementation of GIS-based accessibility analysis for small local food transport were compiled on the basis of survey data. Berry farms were set to be the potential sites for collection as their logistics is usually rather underdeveloped. Also the degree of processing around berry production is relatively low and its food safety regulations are lighter. In addition, the most active producers transporting products, according to the survey, were outdoor horticultural producers. Five routes were selected to represent the transport fleet with the idea of daily routes during one week, which proxies the operations of a small-sized food logistics company. Transportation is most frequent during the growing season when it is done daily or even several times a day. Time-distance for each delivery route was set to be 3, 6 or 9 hours. These values represent the current average duration of farmers' own deliveries and duration of farmers' own deliveries when doubled (since the farmers were mostly willing to drive twice as much as they typically do) and considering official maximum driving time per day for transport work. These together simulate small-scale collection and logistics activities with reasonable empirical relevance and executable parameterisation.

Accessibility indices for local a food collection centre show that berry production can be collected effectively from a relatively large area by relatively modest limited resources (Figure 3 ). There would be an opportunity to build collection logistics with only five three-hour routes to reach $415.5 \mathrm{t}(63.7 \%)$ of berries when total production of the area is $652.1 \mathrm{t}$ (Table 2). However, there are remarkable areal differences in opportunities to establish an effective collection network. The most suitable sites can be found in southern parts of the region between and within Ylivieska and Siikalatva, where the potential reach production areas is over $90 \%$ in comparison to the most efficient site. Thus, this area is clearly suitable as a collection site, where an accurate location is not a key factor.

Tab 2. Accessibility of berries from potential collection sites by five three-hour-long routes.

\begin{tabular}{|c|c|c|c|c|c|c|c|}
\hline \multirow[b]{2}{*}{ Type of berry } & \multirow[b]{2}{*}{$\begin{array}{l}\text { Farms } \\
(\mathrm{N})\end{array}$} & \multirow[b]{2}{*}{$\begin{array}{l}\text { Production } \\
\text { sum (t) }\end{array}$} & \multicolumn{3}{|c|}{ Accessible berry production $(\mathrm{t})$} & \multicolumn{2}{|c|}{$\begin{array}{l}\text { Nodes } \\
\text { accessing berry } \\
\text { production }\end{array}$} \\
\hline & & & $\begin{array}{l}\text { From most } \\
\text { accessible } \\
\text { node }\end{array}$ & $\begin{array}{l}\text { Average } \\
\text { of all } \\
\text { nodes }\end{array}$ & $\begin{array}{l}\text { From least } \\
\text { accessible } \\
\text { node }\end{array}$ & $\begin{array}{l}90 \% \text { of } \\
\max \end{array}$ & $\begin{array}{l}50 \% \text { of } \\
\max \end{array}$ \\
\hline All berries & 212 & 652.1 & 415.5 & 257.2 & 3.1 & 21 & 167 \\
\hline Strawberry & 109 & 587.7 & 415.8 & 241.1 & 2.9 & 12 & 151 \\
\hline Blackcurrant & 106 & 41.1 & 36.4 & 19.5 & 0.12 & 36 & 134 \\
\hline Raspberry & 45 & 11.8 & 10.0 & 6.1 & 0.08 & 11 & 156 \\
\hline Sea buckthorn & 36 & 8.8 & 8.1 & 4.7 & 0 & 10 & 141 \\
\hline
\end{tabular}




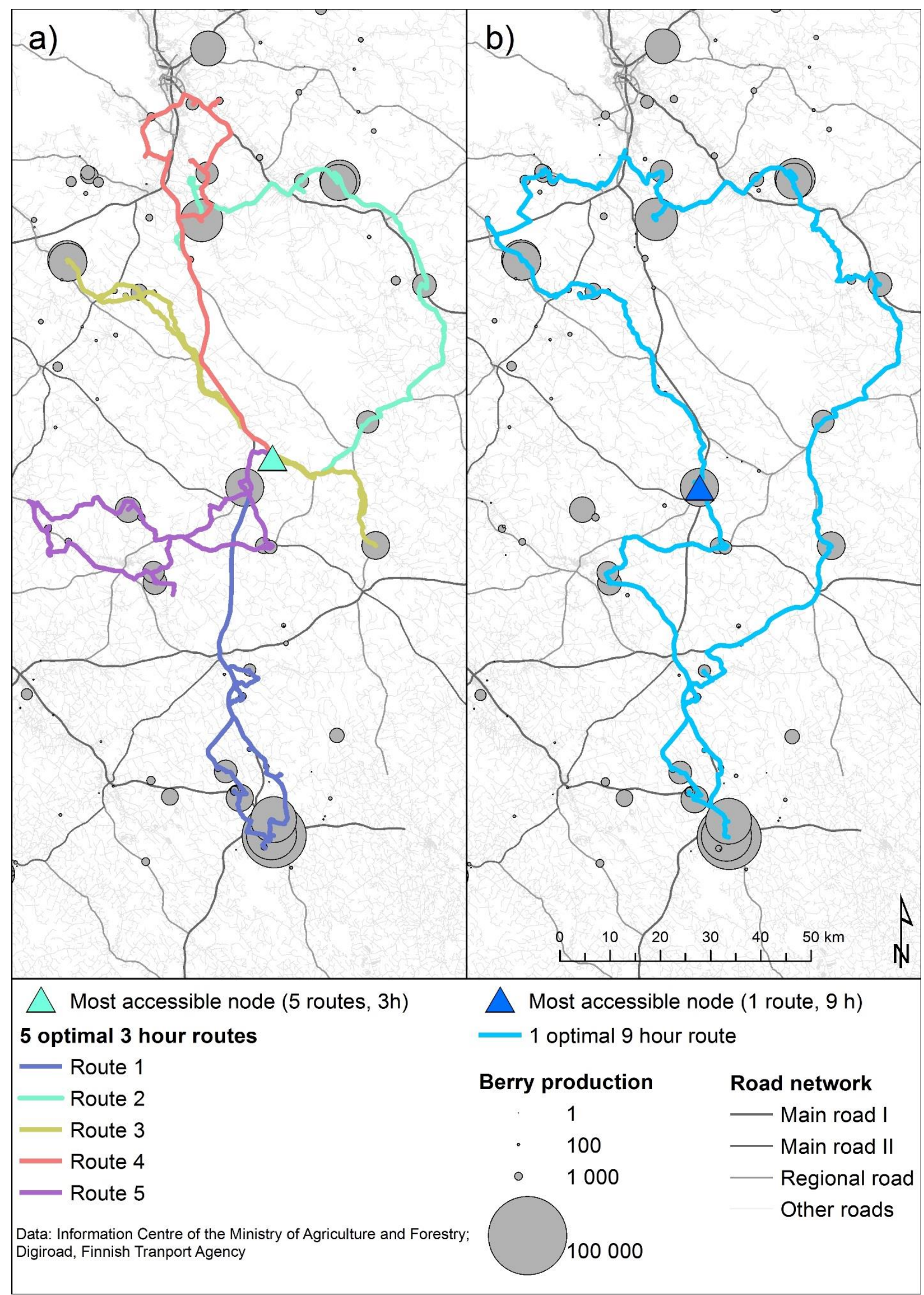

Fig 2. Examples of optimised collection routes. Five optimised three-hour collection (a) routes and one optimised ninehour route (b). 


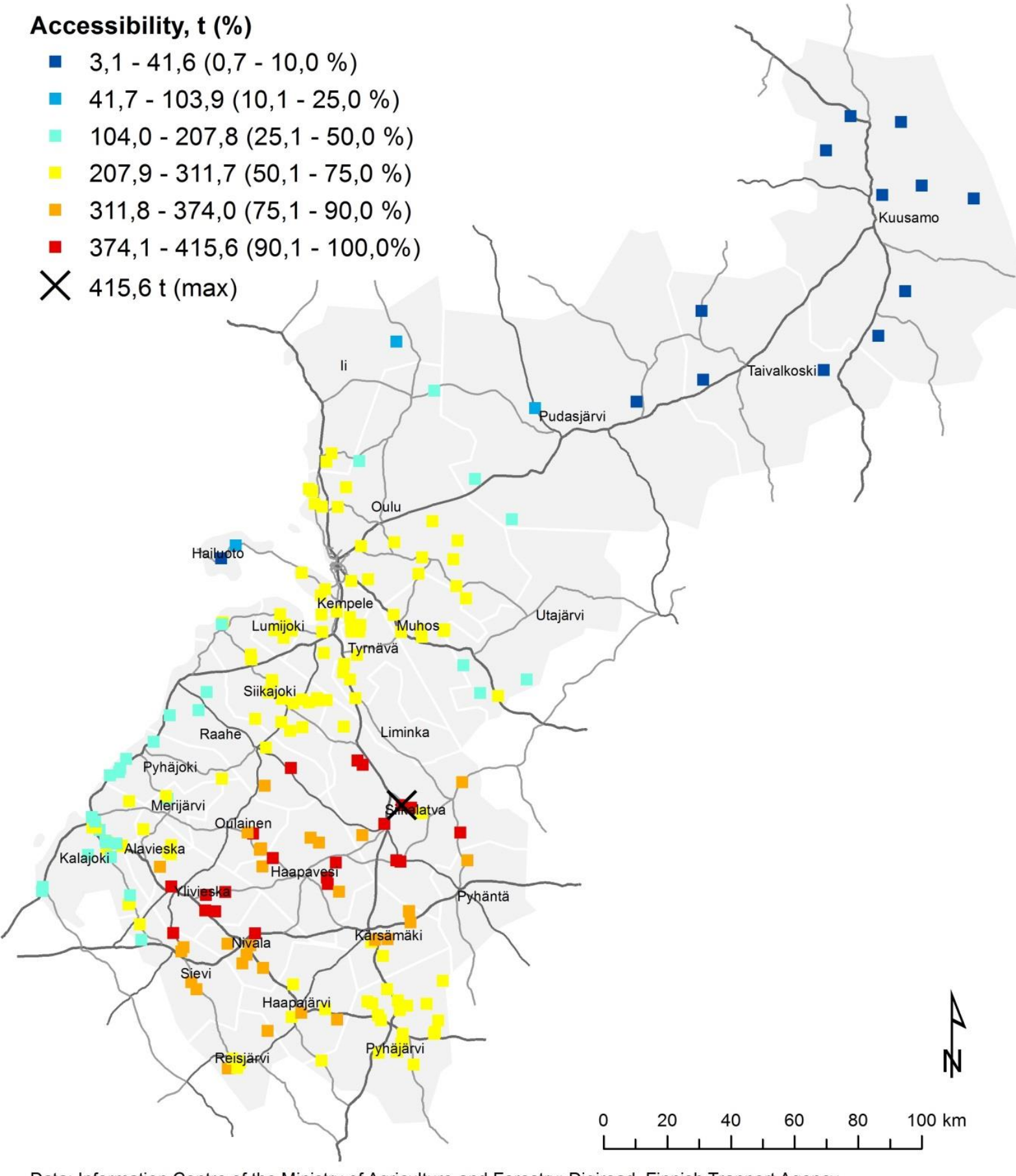

Data: Information Centre of the Ministry of Agriculture and Forestry; Digiroad, Finnish Tranport Agency

Fig 3. Accessibility to berry production from berry farms by optimal collection routes.

When accessibility of berries (sea buckthorn, raspberry, black currant and strawberry) are analysed separately, spatial variation of highest opportunities in reaching production are again located to southern parts of the study area, in general. By further inspection (of Fig. 4), maximal opportunities to reach different berry types exist via collection routes within an area separated by 50-60 kilometres.

However, opportunities to collect over $90 \%$ of the production of different berries in relation to the computational maximum are available at several sites. Again, these relatively high opportunities to reach different berry types are overlapping in various sites. Strawberry has the most eastern emphasis in Siikalatva. The best sites to collect sea buckthorn have mostly a northern emphasis. Sites to reach black currant production efficiently are more spread out and 
located in southern areas, whereas the best raspberry collection sites are found in the middle in relation to the other areas.

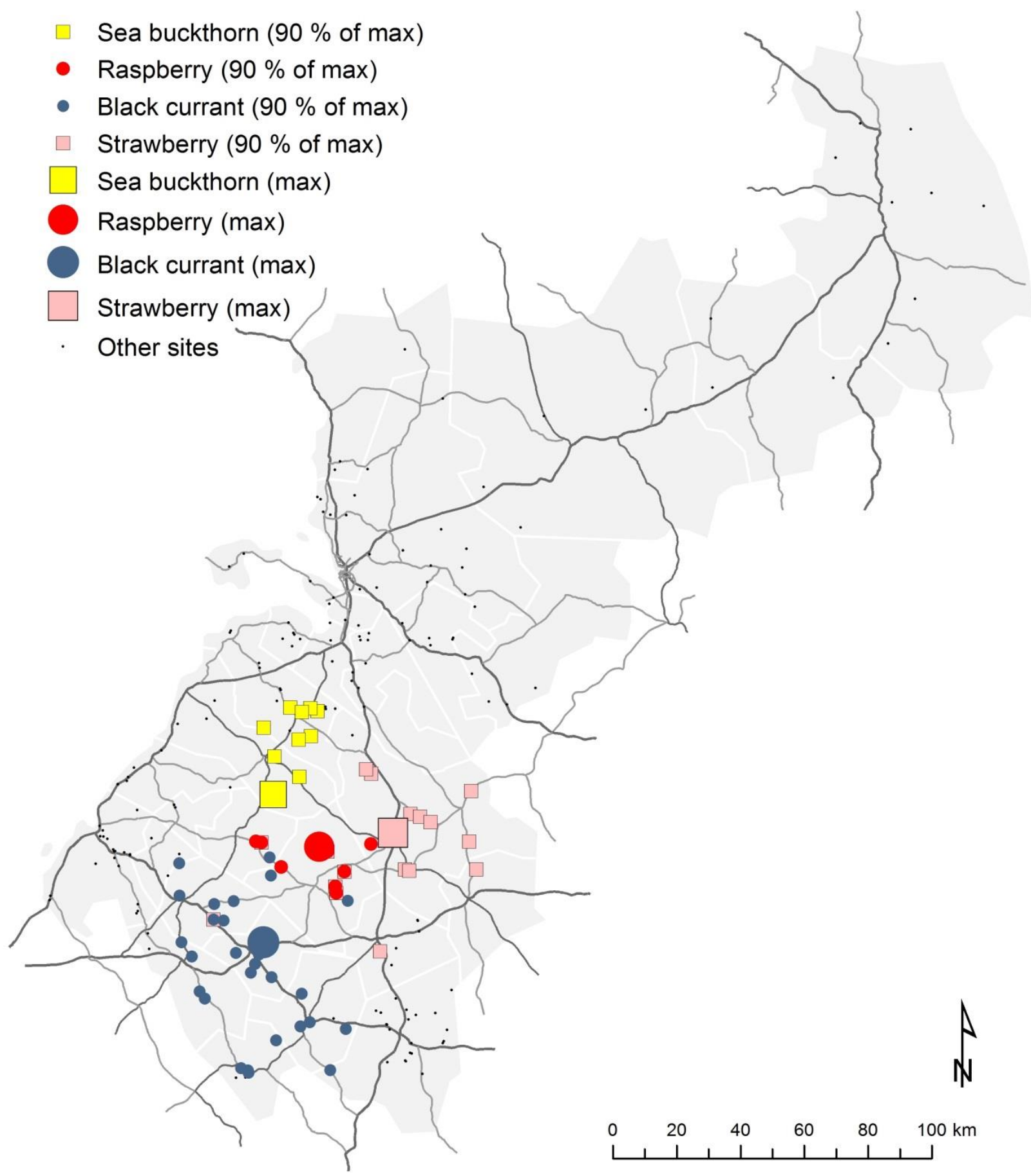

Data: Information Centre of the Ministry of Agriculture and Forestry; Digiroad, Finnish Tranport Agency

Fig 4. Accessibility to berry production by type.

Efficiency of different sites regarding opportunities to reach berry production was evaluated also with different routing settings (Fig. 5). Three-hour routes represent a current average duration of farmers' own deliveries. In addition, six- and three-hour routes were included in the analysis for proxying full-time logistics operator capacity. The key finding with this analytical setting is that the location of a collection site could be anywhere within the southern half of the study area, but the most efficient locations are within Siikalatva and Siikajoki. However, efficiency of transports with regard to ton-kilometre accumulation becomes poor, when most peripheral farms with minor production are included in the network. Another interesting finding is that only one nine-hour route 
could be used to cover $408.1 \mathrm{t}(62.6 \%)$ of berry production, which is almost as much as with five three-hour routes (Table 3). In practice, this means that about two-thirds of the berry production areas could be covered with a single daily route. Again, only the three-hour route could reach one-third of the total production in the study area. Five six-hour routes could cover almost all berry production in the area, and by increasing route lengths further, only a slight increase could be gained.

$\triangle 9 \mathrm{~h}$ routes $(\max )$

$6 \mathrm{~h}$ routes $(\max )$

- $3 \mathrm{~h}$ routes $(\max )$

$\Delta \mathrm{h}$ routes $(90 \%$ of $\max )$

- $6 \mathrm{~h}$ routes $(90 \%$ of $\max )$

$3 \mathrm{~h}$ routes $(90 \%$ of $\max )$

- Other sites

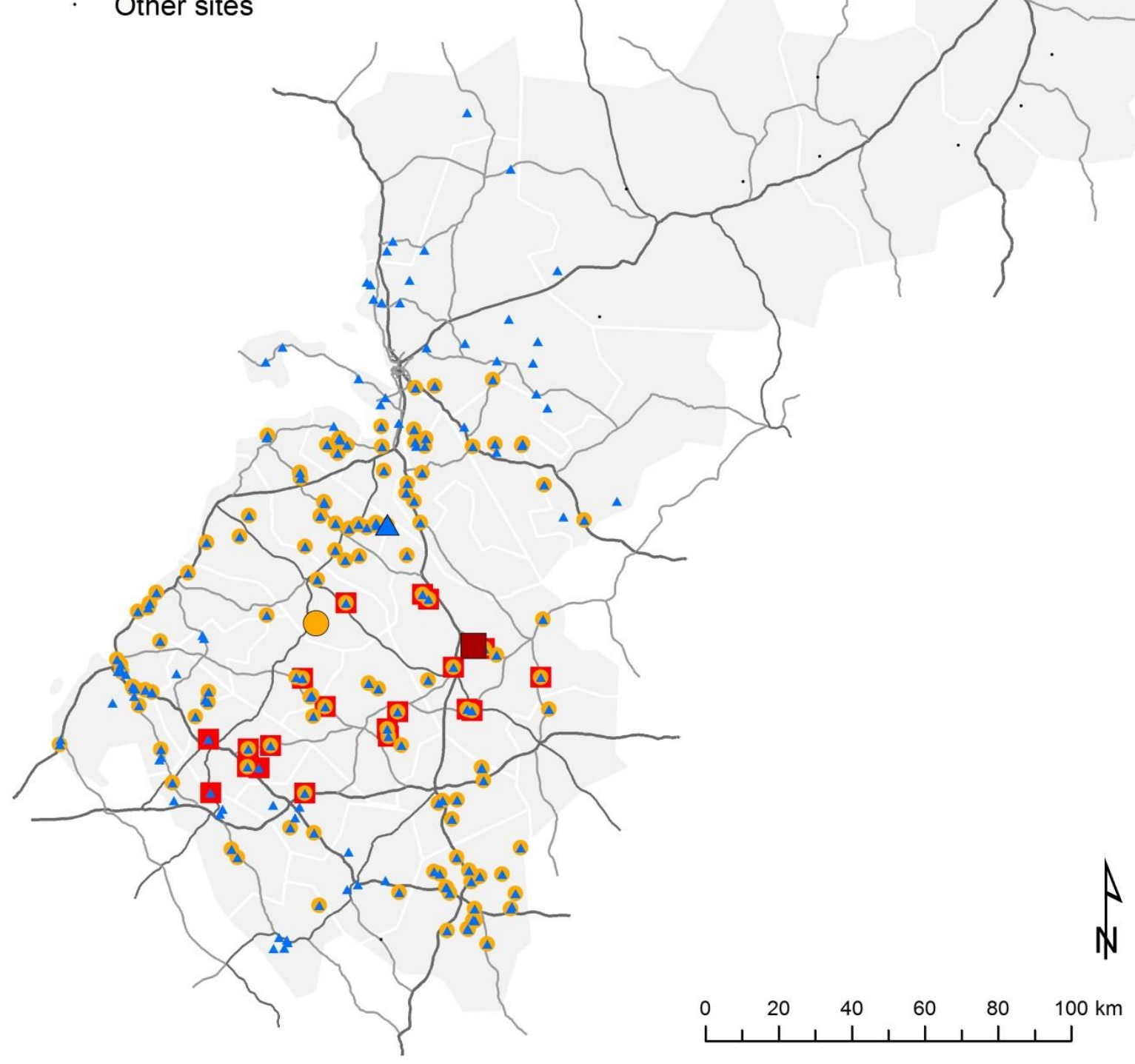

Data: Information Centre of the Ministry of Agriculture and Forestry; Digiroad, Finnish Tranport Agency

Fig 5. Accessibility to berry production by different route times. 
Tab 3. Effect of transport time-distance and fleet size on accessibility of berry production (total 652.1 t) from potential collection sites.

\begin{tabular}{|l|l|l|l|l|}
\hline & Travel time max. & $\begin{array}{l}\text { Collected max } \\
\text { value }(\mathrm{t})\end{array}$ & $\begin{array}{l}\text { Sites }<90 \% \text { of } \\
\max (\mathrm{N})\end{array}$ & $\begin{array}{l}\text { Sites }<50 \% \text { of } \\
\max (\mathrm{N})\end{array}$ \\
\hline \multirow{3}{*}{1 route } & 3 & 218.2 & 29 & 126 \\
\cline { 2 - 5 } & 6 & 353.1 & 28 & 193 \\
\cline { 2 - 5 } & 9 & 408.1 & 147 & 200 \\
\hline \multirow{3}{*}{5 routes } & 3 & 415.5 & 21 & 167 \\
\cline { 2 - 5 } & 6 & 627.8 & 133 & 198 \\
\cline { 2 - 5 } & 9 & 646.7 & 197 & 202 \\
\hline
\end{tabular}

\section{Conclusions}

Rapidly expanding consumer demand for local food has increased the supply of it in various distribution channels. Also, food-processing companies have realised the market value of local products and are interested in using them more. The expansion of operations in small individual companies with short value chain, however, can quickly lead to excessive logistics costs and the need for development, especially in distribution, has been noted as highly relevant in previous studies.

The questionnaires and interviews from this study clearly show that local food supply does not meet the demand well enough. Small producers have problems accessing the markets since supplied batches are small, supply reliability is not strong and branding is often at a weak level. This study focused on analysing potentials of collection logistics in the case of berry production in Northern Ostrobothnia. The spatial analytical market analysis framework, which was applied in this study, is often applied by large companies, but this type of strategic information could benefit also small farms and companies in the food sector. As the study is funded by public rural development funds, the analysis of this paper could be made openly available for the study region's farmers and producers, as access to markets could be enhanced remarkably by arealevel logistics operators, packagers, refiners and marketing operators.

Presently, one of the most important distribution channels for agricultural producers seemed to be local food processing companies, and the market areas of small food processing companies involved in the study were mostly local. Nonetheless, agricultural producers and food processing companies see that problems in successful trading with local actors are, in addition to price level, requirements related to the amounts of supply, lack of knowledge about potential customers and their needs as well as problems related to logistics. Food processing companies see that key shortcomings can be found from logistics requiring larger amounts of supply including cooperation of farmers, processors and consumers. This, however, would require the establishment of a local food wholesaler or other logistics integrating local products. Only a few producers had organised joint transport of products to customers but about a third reported that they transport products on their own instead. Transportation was the most frequent during the growing season and it was done daily or even several times a day, most commonly by vans.

In the study, geographic spaces of local food markets consisting of supply, demand potential hubs and were analysed with an unprecedented spatial accuracy by implementation of GIS. A key finding is that collection logistics of berries could be organised effectively in southern parts of the study area, moderately in the central parts of the area and poorly in the northernmost parts of the area. Again, analysis shows that collection logistics of berries could be efficient at a small capacity, as a relatively restricted route setting could cover well the key producers. Tested five routes having a length of three hours or one route having a length of nine hours could cover approximately two-thirds of the berry production capacity in the area. Due to fine preservation of the product in the case of berry production it might be more beneficial to operate with five shorter routes and deliver products to consumers, for preservation or further processing during the same day.

This study analysed the opportunities to connect berry production with centralised logistics activities, but the methods are applicable also to all other types of foods, and it can be applied 
wherever suitable road network and food production data are available. However, we have to note that for small-scale entrepreneurs, establishing this type of activities would be challenging due to lack of information in relation to producers. Also, it seems at least in the research area many producers are still quite used to working on their own and cooperation cannot be forced or persuaded. Nonetheless, there seems to be a slowly emerging level of cooperation that covers different production lines among producers who mainly deliver their products directly to consumers. But in a broader context, establishing this type of logistics activities requires more exploring of suitable operators and business models.

Finally, this study also considered opportunities to enhance and develop local food value chain in sight of small producers. Between the traditional large scale food industry and alternative local food entrepreneurship, there are only a little intermedia scale food companies operating at local and regional level. The study analysed how the intermediate scale logistics would be functional to serve farmers with interest to expand their market area and also a greater amount of consumers that are willing to buy local food with ease. It is important that the value chain meets the consumer's expectations on local food markets despite the possible clustering in some part of the food chain. The clustering opportunities represented in this paper would probably meet the expectations of the majority of consumers since the logistics remain in the market area, i.e. in the region. The joint transportation doesn't imply that the origin of the product gets blurred which is very essential for consumers. In a broader sense it would reduce the environmental impacts of transportation while there wouldn't be numbers of separate transportations. Of course some consumers are willing to buy products specifically face-to-face from farmers but still the majority wants to buy local food with ease and along with other grocery shopping. Also the access of local food in institutional kitchens would improve from the viewpoint of supply volumes.

\section{Acknowledgements}

This research is based on the project Accessibility of local and organic food in Northern Ostrobothnia (RUOKAGIS) which was funded from the European Agricultural Fund for Rural Development by the Centre for Economic Development, Transport and the Environment in Northern Ostrobothnia. Finalising of this study was carried out within the project Balancing Local Politics, Housing Preferences and Sustainability in the New Detached Housing Areas in the RuralUrban Interaction Zones (BALANCE) which was funded by the Academy of Finland. We wish to express warm thanks to Northern Ostrobothnia's local farmers and food entrepreneurs for their efforts in responding to questionnaires and interviews.

Academic references

[1] Baldacci, R., Toth, P. \& Vigo, D. (2010). Exact algorithms for routing problems under vehicle capacity constraints. Annals of Operations Research 175(1): 213-245. DOI: $10.1007 / \mathrm{s} 10479-009-0650-0$.

[2] Beckie, M., Huddart Kennedy, E. \& Wittman, H. (2012). Scaling up alternative food networks: farmers' markets and the role of clustering in western Canada. Agriculture and Human Values 29(3), 333-345. DOI: 10.1007/s10460-012-9359-9.

[3] Berti, G. \& Mulligan, C. (2016). Competitiveness of small farms and innovative food supply chains: The role of food hubs in creating sustainable regional and local food systems. Sustainability 8(7), 616. DOI: 10.3390/su8070616.

[4] Blanquart, C., Gonçalves, A., Vandenbossche, L., Kebir, L., Petit, C. \& Traversac, J.-B. (2010). The logistics leverages of short food supply chains performance in terms of sustainability [Author manuscript]. $12^{\text {th }}$ World Conference on Transport Research, Lisbonne, Portugal. 
[5] Bloom, J. D. \& Hinrichs, C. C. (2011). Moving local food through conventional food system infrastructure: Value chain framework comparisons and insights. Renewable Agriculture and Food Systems 26 (1), 13-23. DOI: 10.1017/S1742170510000384.

[6] Bosona, T. G. \& Gebresenbet, G. (2011). Cluster building and logistics network integration of local food supply chain. Biosystems engineering 108(4), 293-302. DOI: 10.1016/j.biosystemseng.2011.01.001.

[7] Bosona, T., Nordmark, I., Gebresenbet, G. \& Ljungberg, D. (2013). GIS-based analysis of integrated food distribution network in local food supply chain. International Journal of Business and Management 8(17), 13-34. DOI: 10.5539/ijbm.v8n17p13.

[8] Brown, C. (2003). Consumers' preferences for locally produced food: A study in southeast Missouri. American Journal of Alternative Agriculture 18(4), 213-224. DOI: 10.1079/AJAA200353.

[9] Brunori, G., Galli, F., Barjolle, D., van Broekhuizen, R., Colombo, L., Giampietro, M., Kirwan, J., Lang, T., Mathijs, E., Maye, D., de Roest, K., Rougoor, C., Schwarz, J., Schmitt, E., Smith, J., Stojanovic, Z., Tisenkopfs, T. \& Touzard, J.-M. (2016). Are Local Food Chains More Sustainable than Global Food Chains? Considerations for Assessment. Sustainability 8(5), 449. DOI: $10.3390 /$ su8050449.

[10] Campbell, J. F. (1996). Hub location and the p-hub median problem. Operations Research, 44(6), 923-935. DOI: 10.1287/opre.44.6.923.

[11] Csapó, J. \& Wetzl, V. (2016). Possibilities for the Creation of Beer Routes in Hungary: A Methodological and Practical Perspective. European Countryside 8:3, 250-262. DOI: 10.1515/euco-2016-0018.

[12] Day-Farnsworth, L., MacCown, B., Miller, M. \& Pfeiffer, A. (2009). Scaling Up: Meeting the Demand for Local Food. Madison: University of Wisconsin.

[13] Donald, B. (2009). Contested Notions of Quality in a Buyer-Driven Commodity Cluster: The Case of Food and Wine in Canada. European Planning Studies 17(2), 263-280. DOI: $10.1080 / 09654310802553522$.

[14] Edward-Jones, G., Milà i Canals, L., Hounsome, N., Truninger, M., Koerber, G., Hounsome, B., Cross, P., York, E. H., Hospido, A., Plassmann, K., Harris, I. M., Edwards, R. T., Day, G. A. S., Tomos, A. D., Cowell, S. J. \& Jones, D. L. (2008). Testing the assertion that 'local food is best': the challenges of an evidence-based approach. Trends in Food Science \& Technology 19(5), 265-274. DOI: 10.1016/j.tifs.2008.01.008.

[15] Feldmann, C. \& Hamm, U. (2015). Consumers' perceptions and preferences for local food: A review. Food Quality and Preference, 40/A, 152-164. DOI: 10.1016/j.foodqual.2014.09.014.

[16] Forsman, S. (2004). How do small food-processing forms compete? A Resource-based approach to competitive strategies. Agricultural and Food Science in Finland, 13(Supplement).

[17] Halweil, B. (2002). Home Grown. The Case for Local Food in a Global Market. Washington, DC: Worldwatch Institute.

[18] Harris, E. M. (2010). Eat Local? Constructions of Place in Alternative Food Politics. Geography Compass 4(4), 355-369. DOI: 10.1111/j.1749-8198.2009.00298.x.

[19] Miller, H. J. \& Shaw, S. L. (2001). Geographic information systems for transportation: principles and applications. Geography Compass 9(4), 180-189. DOI: 10.1111/gec3.12204.

[20] Isoniemi, M., Mäkelä, J., Arvola, A., Forsman-Hugg, S., Lampila, P., Paananen, J. \& Roininen, K. (2006). Kuluttajien ja kunnallisten päättäjien näkemyksiä lähi- ja luomuruoasta. Helsinki: Kuluttajatutkimuskeskus. 
[21] Järvelä, M., Jokinen, P., Huttunen, S. \& Puupponen, A. (2009). Local food and renewable energy as emerging new alternatives of rural sustainability in Finland. European Countryside 1(2), 113-124. DOI: 10.2478/v10091/009-0010-8.

[22] Klose, A. \& Drexl, A. (2005). Facility location models for distribution system design. European Journal of Operational Research 162(1), 4-29. DOI: 10.1016/j.ejor.2003.10.031.

[23] Kneafsey, M., Venn, L., Schmutz, U., Balázs, B., Trenchard, L., Eyden-Wood, T., Bos, E., Sutton, G. \& Blackett, M. (2013). Short Food Supply Chains and Local Food Systems in the EU. A State of Play of their Socio-Economic Characteristics. Sevilla: European Commission, Joint Research Centre.

[24] Kotavaara, O., Korhonen, K., Miettinen, M., Lehtinen, U., Muilu, T., Juga, J. \& Rusanen, J. (2014). Lähi- ja luomuruoan saavutettavuus Pohjois-Pohjanmaalla. Helsinki: MTT.

[25] Kurunmäki, S., Ikäheimo, I., Syväniemi, A.-M. \& Rönni, P. (2012). Lähiruokaselvitys. Ehdotus lähiruokaohjelman pohjaksi 2012-2015. Helsinki: Ministry of Agriculture and Forestry.

[26] Lagnevik, M., Sjoholm, I., Lareke. A. \& Ostberg, J. (2003). The dynamics of innovation clusters: A study of the food industry. Cheltenham: Edward Elgar.

[27] Lawson, R., Guthrie, J., Cameron, A. \& Fischer, W. C. (2008). Creating value through cooperation: An investigation of farmers' markets in New Zealand. British Food Journal 110(1), 11-25. DOI: 10.1108/00070700810844768.

[28] Marsden, T., Banks, J. \& Bristow, G. (2000). Food supply chain approaches: exploring their role in rural development. Sociologia Ruralis 40(4), 424-438. DOI: 10.1111/1467$\overline{9523} . \overline{00} \overline{158 .}$

[29] Mononen, T. (2006). Yhteiskuntatieteellisen elintarviketutkimuksen linjoja. In Mononen, T. \& Silvasti, T., eds., Ruokakysymys. Näkökulmia yhteiskuntatieteelliseen elintarviketutkimukseen (pp. 26-52). Helsinki: Gaudeamus Kirja / Oy Yliopistokustannus University Press.

[30] Morgan, K. (2008). Greening the realm: sustainable food chains and the public plate. Regional Studies 42(9), 1237-1250. DOI: $10.1080 / 00343400802195154$.

[31] Muilu, T., Jansik, C., Wuori, O. \& Lehtonen, O. (2016). Suomen keskittyvä elintarviketeollisuus. Maaseudun uusi aika 3, 39-52.

[32] Nagy, G. \& Salhi, S. (2007). Location-routing: Issues, models and methods. European Journal of Operational Research 177(2), 649-672. DOI: 10.1016/j.ejor.2006.04.004.

[33] Norberg-Hodge, H., Merrifield, T. \& Gorelick, S. (2002). Bringing the food economy home Local alternatives to global agribusiness. London: Zed Books.

[34] Páez, A., Scott, D. M. \& Morency, C. (2012). Measuring accessibility: positive and normative implementations of various accessibility indicators. Journal of Transport Geography 25, 141153. DOI: 10.1016/j.jtrangeo.2012.03.016.

[35] Piilo, T. (2003). Sujuva logistiikka ratkaisee pk-yrityksen menestyksen. Kehittyvä elintarvike 6, 22-23.

[36] Porter, M. (1985). Competitive Advantage: Creating and Sustaining Superior Performance. New York NY. The Free Press.

[37] Porter, M. (1998). On competition. New York: HBS.

[38] Puoskari, S., Wuori, O., Korhonen, K. \& Muilu, T. (2013). Lähiruoan lisääminen kuntien julkisissa hankinnoissa Kainuussa ja Pohjois-Pohjanmaalla. Helsinki: MTT.

[39] Renting, H., Marsden, T. K. \& Banks, J. (2003). Understanding alternative food networks: exploring the role of short food supply chains in rural development. Environment and Planning A 35(3), 393-411. DOI: 10.1068/a3510. 
[40] Saito, H. \& Saito, Y. (2013). Motivations for Local Food Demand by Japanese Consumers: A Conjoint Analysis with Reference-Point Effects. Agribusiness 29(2), 147-161. DOI: 10.1002/agr.21315.

[41] Seppänen, L., Aro-Heinilä, E., Helenius, J., Hietala-Koivu, R., Ketomäki, H., Mikkola, M., Risku-Norja, H., Sinkkonen, M. \& Virtanen, H. (2006). Paikallinen ruokajärjestelmä: ympäristö- ja talousvaikutuksia sekä oppimishaasteita. Helsinki: Helsingin yliopisto.

[42] Spiekermann, K., Wegener, M., Květoň, V., Marada, M., Schürmann, C., Biosca, O., Segul, A. U., Antikainen, H., Kotavaara, O., Rusanen, J., Bielańska, D., Fiorello, D., Komornicki, T., Rosik, P. \& Stepniak, M. (2015). TRACC, Transport Accessibility at Regional/Local Scale and Patterns in Europe TRACC Accessibility Indicator Factsheets [Final Report. Vol 4]. Luxembourg: ESPON.

[43] Seyfang, G. (2006). Ecological citizenship and sustainable consumption: Examining local organic food networks. Journal of Rural Studies 22(4), 383-395. DOI: 10.1016/j.jrurstud.2006.01.003.

[44] Viitaharju, L., Määttä, S., Hakala, O. \& Törmä, H. (2014). Työtä ja hyvinvointia! Lähiruoan käytön aluetaloudelliset vaikutukset Suomen maakunnissa. Helsinki: Helsingin Yliopisto.

[45] Virtanen, M., Heikkilä, L. \& Eerikäinen, H. (2014). Arvoketju ja liiketoimintamahdollisuuksien kehittäminen. In Heikkilä, L., eds., Ruoka lähellä, kuluttaja kaukana? Näkökulmia lähiruoan kysynnän ja tarjonnan kohtaamiseen (pp. 40-49). Helsinki: MTT.

[46] Vänttinen, R. \& Korpi-Vartiainen, J.-P. (2010). Lähiruoan käyttö julkisen sektorin ammattikeittiöissä. Suonenjoki: Sisä-Savon Seutuyhtymän julkaisuja.

[47] Wolfe, D. A. \& Gertler, M. S. (2006). Local antecedents and trigger events: Policy implications of path dependency for cluster formation. In Braunerheim, P. \& Feldmand, M., eds., Cluster genesis: Technology-based industrial development (pp. 243-263). Oxford: Oxford University Press.

Other sources

[48] EPRS (2016). Short food supply chains and local food systems in the EU. Briefing September 2016. European Parliamentary Research Service.

<http://www.europarl.europa.eu/RegData/etudes/BRIE/2016/586650/EPRS_BRI(2016)586 650_EN.pdf>

[49] ESRI (2010). Algorithms used by Network Analyst $<$ http://webhelp.esri.com/arcgisdesktop/9.3/index.cfm?TopicName=Algorithms_used_by_N etwork_Analyst>

[50] ETL (2016). Forkful of facts - Finnish food industry statistics 2016. Ruokatieto. $<$ <ttp://www.etl.fi/media/aineistot/tilastot/tietohaarukka2016_englanti.pdf>(EU) No 807/2014

[51] European Commission (2001). Study on the impact of community agricultural policies on economic and social cohesion.

<http://ec.europa.eu/regional_policy/archive/sources/docgener/studies/pac_en.htm>

[52] European Commission (2012). National GPP action plans (policies and guidelines).

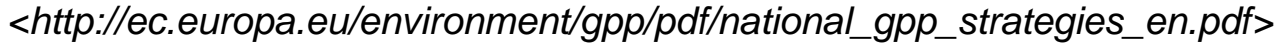

[53] EUROSTAT (2016). <http://ec.europa.eu/eurostat/statistics-explained/index.php/Farm_structure_statistics>

[54] Finland's $72^{\text {nd }}$ government (2013). Local Food - But of Course! Government Programme on Local Food and development objectives for the local food sector to 2020. Ministry of Agriculture and Forestry.

http://mmm.fi/documents/1410837/1890227/LocalFood_ButOfCourse.pdf/ef43072b-670047ad-af7e-5972e7fe046f 
[55] Green public procurement (2008). Europa, Summaries of EU legislation. $<$ http://europa.eu/legislation_summaries/internal_market/businesses/public_procurement/m i0002_en.htm>

[56] Huomisen ruoka (2010). Esitys kansalliseksi ruokastrategiaksi. Ruokastrategian valmistelun johtoryhmä.

http://mmm.fi/documents/1410837/1801180/Huomisen+ruoka+\%E2\%80\%93+Esitys+kansa Iliseksi+ruokastrategiaksi/db6d286f-8e9c-4521-85b5-5b17cfe0cc25

[57] Korhonen, K. \& Muilu, T. (2015). Developing local food cooperation and public procurement in Oulu South region, Finland. Proceedings of the conference. Agriculture in an urbanizing society, 14-17 September 2015, Rome, Italy (pp. 527-528). <https://app.box.com/s/8oaky8n9dnkbu7iuaf9m54t3c0rmsmzx/1/11886889741/996025005 93/1>

[58] MTK (Maa- ja metsätaloustuottajain Keskusliitto) (2011). Lähiruoalle määritelmä. 31.5.2011. <https://www.mtk.fi/ajankohtaista/uutiset/uutiset_2011/fi_Fl/lahiruoalle-maaritelma/>

[59] Maaseutupolitiikan yhteistyöryhmä (2000). Lähiruoan mahdollisuudet. Lähiruokatyöryhmän loppura portti. Maaseutupolitiikan yhteistyöryhmän julkaisu 6/2000. Sisäministeriön monistamo. Helsinki.

[60] OECD (2014). Competition issues in the food chain industry. The OECD Competition Committee.

<https://www.oecd.org/daf/competition/Competition/ssuesintheFoodChainIndustry.pdf>

[61] Piilo, T. (2007). Food Logistics - Providing local food through individual transport and distribution solutions.

<http://www.transveritas.fi/media/Kuljetusketjujen_ymparistoraportointi/Kuljetusten

_kehittaminen_Innoelli_Alma_(englanti).pdfs

[62] Ruoka-Suomi (2013). Elintarvikeyritykset kokoluokittain 6/2013.

<http://www.ruokasuomi.fi/tilastot/taulukko_elintarvikeyritykset_kokoluokittain_2013.pdf>

[63] Valtioneuvosto (2010). Valtioneuvoston selonteko ruokapolitiikasta 14.10. 2010. <https://www.eduskunta.fi/Fl/vaski/Selonteko/Documents/vns_6+2010.pdf>

[64] Valtioneuvosto (2017). Food2030: Finland feeds us and the world. Government report on food policy.

<http://mmm.fi/documents/1410837/1923148/lopullinen03032017ruoka2030_en.pdf/d7e44 e69-7993-4d47-a5ba-58c393bbac28 >

[65] Valtioneuvoston kanslia (2015). Pääministeri Juha Sipilän hallituksen strateginen ohjelma. 29.5.2015.

<http://valtioneuvosto.fi/documents/10184/1427398/Ratkaisujen+Suomi_FI_YHDISTETTY_ netti.pdf/801f523e-5dfb-45a4-8b4b-5b5491d6cc82> 